\title{
LC-MS/MS and RP-HPLC-UV Analysis and Antioxidant Activities of Arum italicum Miller Edible and Nonedible Tuber Parts
}

\author{
Zeynep AKAR $^{1^{*}} \quad$ Çağlar DEMIR $^{1} \quad$ Ozan ALKAN $^{1} \quad$ Zehra CAN $^{2} \quad$ Bülent AKAR $^{3}$ \\ $1^{1^{*}}$ Department of Genetics and Bioengineering, Faculty of Engineering and Natural Sciences, Gümüşhane Universty, Gümüşhane, Turkey \\ ${ }^{2}$ Bayburt University, Faculty of Applied Sciences, Department of Emergency Aid and Disaster Management, Bayburt, Turkey \\ ${ }^{3}$ Department of Food Engineering, Faculty of Engineering and Natural Sciences, Gümüşhane Universty, Gümüşhane, Turkey
}

How to cite: Akar, Z., Demir, C., Alkan, O., Can, Z. \& Akar, B. (2021). LC-MS/MS and RP-HPLC-UV Analysis and Antioxidant Activities of Arum italicum Miller Edible and Nonedible Tuber Parts. J. Anatolian Env. and Anim. Sciences, 6(3), 294-301.

Atıf yapmak için: Akar, Z., Demir, C.., Alkan, O., Can, Z. \& Akar, B. (2021). Arum italicum Miller Bitkisinin Yenilebilir ve Yenmeyen Yumru Parçalarının LC-MS/MS ve RP-HPLC-UV Analizi ve Antioksidan Aktiviteleri. Anadolu Çev. ve Hay. Dergisi, 6(3), 294-301.

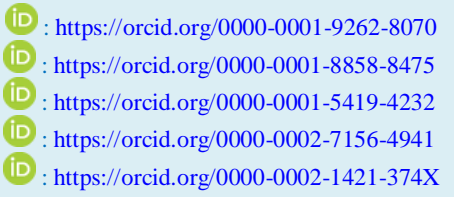

*Corresponding author's: Zeynep AKAR

Department of Genetics and Bioengineering, Faculty of Engineering and Natural Sciences, Gümüșhane University, Gümüșhane, Turkey 凶: zeynep_iskefiyeli@hotmail.com

\begin{abstract}
In the study, the phenolic components and antioxidant activities of edible and nonedible parts of tuber of Arum italicum plant were carried out to determine in methanolic and water extracts. In addition, the antioxidant potential of these parts of the plant was associated with their phenolic composition. Total phenolic content, FRAP, CUPRAC and DPPH tests as radical scavenging activity were performed to determine the antioxidant activity of the plant. The phenolic profiles in the two parts of the tuber were determined in the prepared methanolic extracts by RP-HPLC-UV and LC-MS/MS. The highest values of the total phenolic content, FRAP, CUPRAC and \% DPPH were measured in methanolic extracts of nonedible parts of the tuber as $164 \mu \mathrm{g} \mathrm{GAE} / \mathrm{mL}, 878$ TEAC $(\mu \mathrm{M}), 0.064$ TEAC $(\mu \mathrm{M})$ and 19.41 , respectively. Ferulic acid was determined as the main phenolic compound in methanolic extracts of both the tuber parts by LC/MS-MS. However, luteolin and rutin phenolics were measured as the major compounds in the edible and nonedible parts of the plant tuber with analysis based on RP-HPLC-UV, respectively.
\end{abstract}

\section{Keywords: Antioxidant activity, Arum italicum, LC-MS/MS, Phenolic, RP-HPLC-UV.}

*Sorumlu yazar: Zeynep AKAR Genetik ve Biyomühendislik Bölümü, Mühendislik ve Doğa Bilimleri Fakültesi, Gümüşhane Üniversitesi, Gümüşhane, Türkiye. 凶: zeynep_iskefiyeli@hotmail.com
Öz: Bu çalışmada, Arum italicum bitkisine ait yumrunun yenilebilir ve yenmeyen kısımlarından elde edilen metanolik ve sulu ekstraktların, fenolik içerikleri ve antioksidan aktiviteleri belirlenmiştir. Ek olarak, bitkinin bu kısımlarının antioksidan potansiyeli, fenolik kompoziyonu ile ilişkilendirilmiştir. Bitkinin antioksidan aktivitesini belirlemek için Toplam Fenolik Madde Miktarı, FRAP, CUPRAC ve radikal süpürme aktiviteyi belirleyen DPPH antioksidan aktivite testleri yapılmıştır. Bitki yumrusunun her iki kısmındaki fenolik profiller hazırlanan metanolik ekstraktlarında RP- HPLC-UV ve LC-MS/ MS cihazları kullanılarak belirlenmiştir. En yüksek toplam fenolik içerik, FRAP, CUPRAC ve \% DPPH değerleri, yumrunun yenmeyen kısmının metanolik ekstraktında sırasıyla $164 \mu \mathrm{g}$ GAE $/ \mathrm{mL}, 878 \mathrm{TEAC}(\mu \mathrm{M}), 0.064 \mathrm{TEAC}(\mu \mathrm{M})$ ve 19.41 olarak ölçülmüştür LC/MS-MS ölçümlerinde her iki yumru kısmının metanolik ekstraktlarında ferulik asit, ana fenolik bileşik olarak belirlendi. Bununla birlikte RP-HPLC-UV ölçümlerinde ise, bitki yumrusunun yenilebilir ve yenilmeyen kısımlarında sırasıyla luteolin ve rutin fenolikleri ana bileşikler olarak ölçülmüştür. 


\section{INTRODUCTION}

Free radicals are formed in cells during usual metabolic activity and also various environmental factors such as air pollution, some chemicals, additives, and artificial nutrition are effective in their formation. They damage cells by breaking hydrogen atoms. However, molecules called antioxidant substances stop or minimize the effects of free radicals in the organism and prevent the formation of chain reactions which can cause the occurrence of various diseases. Thus, a balance between free radicals and antioxidants is obligation for cells and tissues to maintain their usual physiological activities. It is known that free radicals increase in the body due to the decline of the body antioxidant protective system. This causes many diseases, mainly cancer (Uttara et al., 2009; Valko et al., 2007). In order to maintain this system in a balanced way it is very important to consume natural compounds with antioxidant activity. Many plants showed high antioxidant, anti-inflammatory, antimicrobial activities due to their phytochemical compound content (Djeridane et al., 2006; Erez et al., 2019; Hirasa \& Takemasa, 1998). Although these compounds called secondary metabolites do not have a direct relationship with the basic vital functions of the plant, they are chemical substances that are at least as important as primary metabolites such as protein, fat, carbohydrate. Plants include compounds having antioxidant activities such as carotenoids, lycopenes, coenzyme-Q, antioxidant vitamins, and phenolics (phenolic acids, flavonols, flavonoids, anthocyanins, lignins and tannins) (Cai et al., 2004; Mau et al., 2002; Ng et al., 2000; Xiao et al., 2000). Plant antioxidants have an important role in reducing of oxidative stress on organisms associated with industrialization and technology. Turkey, which has a rich flora, has great potential for natural antioxidant compounds. Consumed as food Arum italicum Miller in the family Araceae grows naturally in the northern regions of Turkey. Also, it is used as traditional herbal medicines to control some illness such as hemorrhoid, eczema, cancer, blepharitis, stye, abscess, muscle pain and antifebrile (Akbulut \& Özkan, 2014; Bozyel et al., 2020). Generally, the tuber part of the plant is consumed as food boiled. However, the all of tuber part is not consumed as food by local people in Black Sea Region of Turkey. Edible part of the tuber is more delicious than the other part. It is the close to stem of plant and is separated from the nonedible part by a node. The nonedible part of the tuber is not consumed as food due to the unpleasant. Tubers of the plant are also used industrially due to the abundance of starch in the tubers of the plant (Ahmed et al., 2018). There are various antioxidant activity determination methods to detect the antioxidant activities of natural and synthetic components
(Gidik et al., 2019; Tosun et al., 2015). These methods can be classified according to the type of measured antioxidants substance (hydrophilic or lipophilic, enzymatic or nonenzymatic), solvent character (organic or aqueous), reactive type (radical or non-radical) and reaction mechanism (electron transfer and hydrogen atom transfer) (Gülcin, 2012; Huang et al., 2005).

In the study, it was aimed to determine the antioxidant activity of methanolic and water extracts of both edible and nonedible parts of tuber of Arum italicum plant according to four antioxidant activity methods, which are widely used in the literature and have different reaction mechanisms. These methods are \% DPPH Radical Scavenging Activity (Brand-Williams, 1995). Total Phenolic Method with Folin-Ciocalteu Separator (FCR), Iron (III) Reduction/Antioxidant Power (FRAP) Determination (Benzie \& Strain, 1996). Copper (II) Reducing Antioxidant Activity (CUPRAC) (Apak et al., 2004). In addition, the phenolic contents of the methanolic extracts of both parts were determined with RP-HPLCUV and LC-MS/MS devices comparatively.

\section{MATERIALS AND METHODS}

Preparation of Plant Extraction: The tuber parts of the A. italicum plant were collected in March 2017 from the Derecik district of Trabzon-Akçaabat province of Turkey. The edible and the nonedible of the tuber, were separated from each other (Table 1). After these parts were completely dried, they were and grounded into powder with blender. Then, edible and nonedible parts were extracted both water and methanol for two hours in a magnetic stirrer. Filtration of the extracts was performed with passing filter papers and through a 0.45 syringe filter respectively. Finally, the prepared solutions were separated for antioxidant analysis and RP-HPLC-UV phenolic analysis.

For LC/MS-MS, $1 \mathrm{~g}$ of each of the samples was added to $10 \mathrm{~mL}$ solvent $(75 \%$ methanol $+25 \%$ dichloromethane) and the solutions were extracted on the shaker for 2 hours. Then, extracts were filtered and injected into the device with passing through a $0.45 \mu \mathrm{m}$ syringe filter.

Table 1. Abbreviations for solution extracts of tuber of $A$. italicum.

\begin{tabular}{ll}
\hline $1 \mathrm{~S}$ & Edible part of the tuber water extract \\
$1 \mathrm{M}$ & Edible part of the tuber methanol extract \\
$2 \mathrm{~S}$ & Nonedible part of the tuber water extract \\
$2 \mathrm{M}$ & Nonedible part of the tuber methanol extract \\
\hline
\end{tabular}

\section{Determination of Antioxidant Activity}

Total Phenolic Content (TPC): The total phenolic content of the edible part and the nonedible part of the A. italicum plant tuber was determined by using 
Folin-Ciocalteu reagent, modified according to Slinkard and Singleton (1977) method. Firstly, $50 \mu \mathrm{L}$ of sample solution was diluted with $2.5 \mathrm{~mL}$ of distilled water and 250 $\mu 10.2 \mathrm{~N}$ Folin-Ciocalteu reagent was added. Then $750 \mu \mathrm{l}$ of $\mathrm{Na}_{2} \mathrm{CO}_{3}(7.5 \%)$ was put in the mixture and vortexed. The tubes were incubated at room temperature for 2 hours and the absorbance values at $765 \mathrm{~nm}$ were measured. The amounts of phenolic compounds in the samples were calculated in terms of gallic acid equivalent (GAE $\mu \mathrm{g} / \mathrm{mL}$ ) with using the function of the line obtained from the standard calibration graph of gallic acid prepared at six different concentrations (starting at $1000 \mu \mathrm{g} / \mathrm{mL}$ ).

\section{Determination of Iron (III)}

Reduction/Antioxidant Power (FRAP): Edible part and non-edible of the plant tuber were studied at a concentration of $100 \mathrm{mg} / \mathrm{mL}$ based on the FRAP method developed by Benzie and Strain (1996). As in determination of TPC, Trolox antioxidant standard was studied in six different concentrations (starting at 1000 $\mu \mathrm{M})$. Samples were pipetted as triplicate together with a sample and reagent blank. After 20 minutes, the absorbance values were read at $595 \mathrm{~nm}$. The results were calculated as $\mu \mathrm{M}$ TEAC comparing with the standard antioxidant substance Trolox.

Copper (II) Reducing Antioxidant Activity (CUPRAC): The method developed by Apak et al (2004) was modified and applied in this study. $\mathrm{Cu}$ (II) chloride and neocuproine solution, ammonium acetate buffer $(\mathrm{pH}=7)$ and analysis solutions were added in equal volumes respectively. The volume of final solution was adjusted to $4.1 \mathrm{~mL}$ After 30 minutes, absorbance values were measured at $450 \mathrm{~nm}$. As in FRAP, the antioxidant capacities of the samples in terms of Trolox equivalent were calculated as $\mu \mathrm{M}$ TEAC with using values obtained from the standard antioxidant Trolox graph studied at six different concentrations (starting from $1000 \mu \mathrm{M}$ ).

DPPH Radical Scavenging Activity: In DPPH scavenging activity, $100 \mu \mathrm{M}$ methanolic solution of DPPH radical was used to determine the activity of edible and non-edible parts of the tuber of the plant. The antioxidant standard and the extracts of the tuber parts of A. italicum were conducted in triplicate. In addition, a sample and a reagent blank were studied for each concentration of the samples. After the incubation period $(50 \mathrm{~min})$, the absorbance values of the solutions mixed with DPPH reagent were read at $517 \mathrm{~nm}$ and the \% inhibition (DPPH• scavenging) values were calculated (Huang et al., 2005). $\%$ inhibition (DPPH• cleaning) values were calculated using the following formula.

$\%$ Inhibition (radical cleaning power $)=\left[\left(\mathrm{ADPPH}_{-}\right.\right.$ Asample) / ADPPH] X 100

ADPPH: Absorbance value of the DPPH solution

Asample: Absorbance value of the sample extract

\section{HPLC-UV \\ Determination of Phenolic Components by}

RP-HPLC-UV Conditions: Analysis of phenolic compounds was carried out on HPLC (Elite LaChrom Hitachi Japan) device. The analysis were performed with using a reverse phase $\mathrm{C} 18$ (150 $\mathrm{mm} \times 4.6 \mathrm{~mm}, 5 \mu \mathrm{m}$; Fortis) column. In this process, the gradient program was applied containing $2 \%$ acetic acid (pure water) in a reservoir and $70 \%$ acetonitrile (pure water) in B reservoir (Can et al., 2015). In addition, it is optimized that the injection volumes of the standards and samples to $20 \mu \mathrm{L}$, the flow of mobile phase to $1.0 \mathrm{~mL} / \mathrm{min}$, and temperature of the column to $30{ }^{\circ} \mathrm{C}$ were fixed. In addition, for the gradient program the optimization was performed with passing through reservoir A as follows: $95 \%$ for $0-3$ minutes, $85 \%$ for $5-8$ minutes, $80 \%$ for $8-10$ minutes, $75 \%$ for $10-12$ minutes, $60 \%$ for $12-20$ minutes, $20 \%$ for $20-30$ minutes and $95 \%$ for 35-50 (Can et al., 2015).

LC-MS/MS Analysis: Phenolic component analysis was performed with LC-MS/MS Thermo Scientific/Dionex Ultimate 3000-TSQ Quantum device. LC-MS/MS analyzes were carried out by Hitit University Scientific Technical Application and Research Center. The analyses were performed using ODS Hypersil $4.6 * 250$ $\mathrm{mm}, 5 \mu \mathrm{m}$ column and applying a gradient program including formic acid, water and methanol. Gradient program with $0.1 \%$ formic acid (pure water) in reservoir $\mathrm{A}$ and $100 \%$ methanol in reservoir B was applied. In addition, it is optimized that it is optimized that the injection volumes of the standards and samples to $20 \mu \mathrm{L}$, the flow of mobile phase to $0.7 \mathrm{~mL} / \mathrm{min}$, and temperature of the column to $30{ }^{\circ} \mathrm{C}$ were fixed. The gradient program was optimized by passing through the reservoir $100 \% \mathrm{~A}$ for 0 1 minutes, $5 \% \mathrm{~A}$ for 3 minutes in 22 minutes, and $100 \% \mathrm{~B}$ for 8 minutes in 26 minutes.

\section{RESULTS AND DISCUSSION}

Antioxidant Activity of A. italicum Extracts: There are many antioxidant activity determination methods. In the study, to determine the antioxidant activity of the plant tuber was used such as total phenolic content, FRAP, CUPRAC and \% DPPH scavenging activity tests.

Total Phenolic Content: Polyphenols, flavonoids and phenolic compounds found in plants are natural antioxidants substances which prevent the harmful effects of oxidative stress induce by ROS. In the study, the total phenolic content of the edible and nonedible parts of the tuber of Arum italicum was determined using different solvents (water and methanol). Total phenolic content of methanolic extracts were determined higher than water extracts. While the $2 \mathrm{M}$ sample showed highest phenolic content it was followed by $1 \mathrm{M}, 2 \mathrm{~S}$ and $1 \mathrm{~S}$, respectively (Figure 1). 

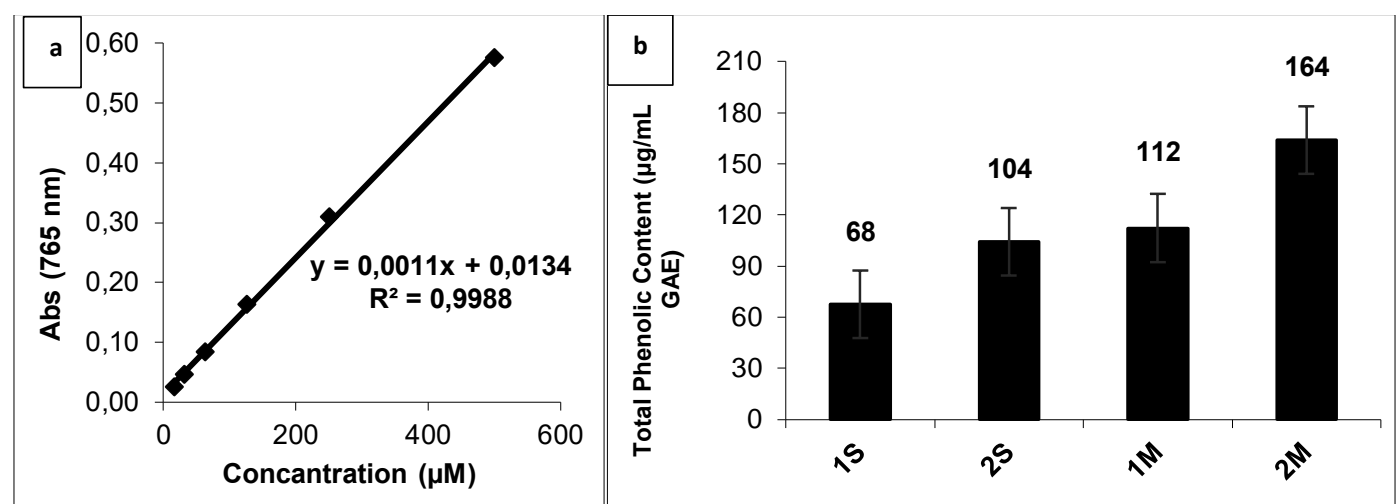

Figure 1. Calibration graphic of the gallic acid standard studied at different concentrations (a) and GAE ( $\mu \mathrm{g} / \mathrm{mL})$ values of the Total Phenolic Content of the water and methanolic extracts of the two parts of the tuber (b).

Karahan et al. (2006) conducted experiments the TPC and TFC activity in the leaves of the Arum dioscoridis Sm. with using different organic solvents (acetone, ethanol, methanol and water). They report that the highest total phenolic and flavonoid contents were in the ethanol and methanol extracts respectively. In our study, also the total phenolic content was found to be higher in both methanolic extracts of edible and nonedible parts. The highest total phenolic content was determined as $164 \mu \mathrm{g} \mathrm{GAE} / \mathrm{mL}$ in sample $2 \mathrm{M}, 112 \mu \mathrm{g} \mathrm{GAE} / \mathrm{mL}$ in $1 \mathrm{M}$ sample, $104 \mu \mathrm{g}$ $\mathrm{GAE} / \mathrm{mL}$ in $2 \mathrm{~S}$ sample, $68 \mu \mathrm{g} \mathrm{GAE} / \mathrm{mL}$ in sample $1 \mathrm{~S}$.
Iron (III) Reduction/Antioxidant Power and Copper (II) Reducing Antioxidant Activity Analysis: The reducing power of bioactive compounds is an indicator of the electron donating ability and this situation is related to the antioxidant activity of the compounds (ArabshahiDelouee \& Urooj, 2007). The antioxidant activity of the plant was determined with methods of FRAP and CUPRAC. In the FRAP test, antioxidant activity values were measured as higher in both water and methanolic extracts of the nonedible tuber part than the edible part (Figure 2).
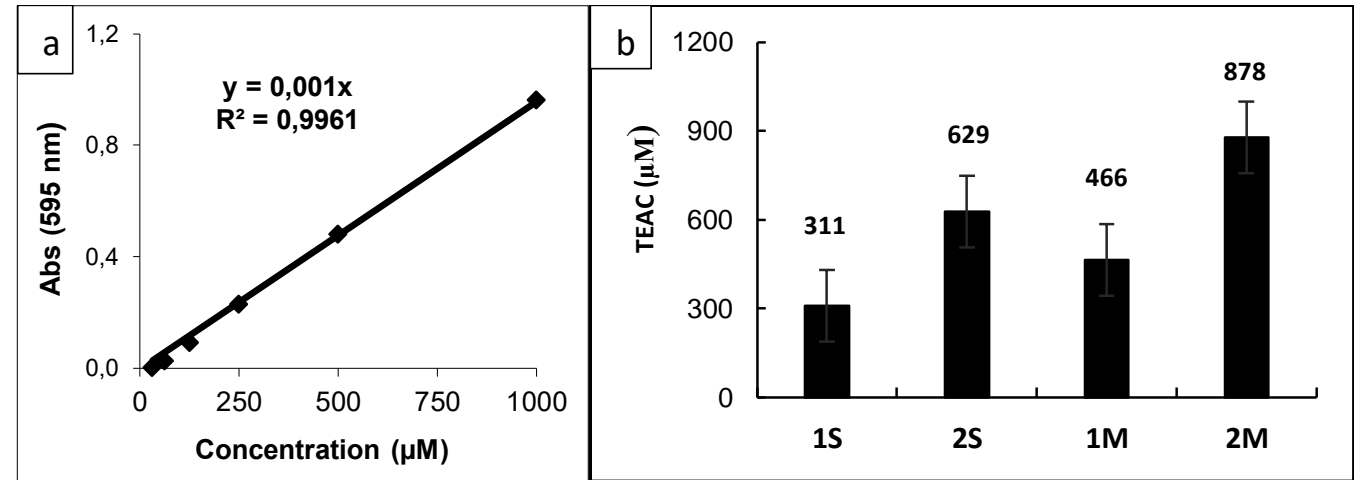

Figure 2. Calibration graphic of the Trolox standard studied at different concentrations (a) and FRAP values ( $\mu$ M TEAC) of water and methanolic extracts of the two parts of the tuber (b).

In CUPRAC test, $\mathrm{Cu}^{+2}$ reduction activity of methanolic extracts was measured higher than the water extracts. In addition, as with FRAP, the highest values of water and methanolic extracts were measured for the nonedible parts in CUPRAC test (Figure 3). FRAP results were determined as 878 TEAC $(\mu \mathrm{M})$ in sample $2 \mathrm{M}, 629$ TEAC $(\mu \mathrm{M})$ in sample $2 \mathrm{~S}, 466 \mathrm{TEAC}(\mu \mathrm{M})$ in sample $1 \mathrm{M}$, and $311 \mathrm{TEAC}(\mu \mathrm{M})$ in sample $1 \mathrm{~S}$. The CUPRAC results were measured as $0.064 \mathrm{TEAC}(\mu \mathrm{M})$ in sample $2 \mathrm{M}, 0.036$ TEAC $(\mu \mathrm{M})$ in sample $1 \mathrm{M}, 0.024 \mathrm{TEAC}(\mu \mathrm{M})$ in sample $2 \mathrm{~S}, 0.018 \mathrm{TEAC}(\mu \mathrm{M})$ in sample $1 \mathrm{~S}$. The CUPRAC results are consistent with the results for the total phenolic content.

Antioxidant Activity Analysis with \% DPPH Method: To determine the antioxidant activities, DPPH free radical scavenging test was applied to water and methanol extracts of both parts of the plant tuber. The
DPPH radical scavenging method is commonly used in measuring the antioxidant activity of the phenolic compounds or plant extracts due to its easy to operate, rapid and sensitive nature (Uguzlar et al., 2012). Many plant extracts have antioxidant properties because they contain phytocomponents such as phenolic acids and flavonoids (Chu et al., 2000). When DPPH activity results were examined for the all the parts of the plant tuber, \% DPPH scavenging activity the methanol extracts was higher than that of the water extracts. In addition, as in all the tests, the highest activity values of \% DPPH in both methanolic and water extracts were found in the nonedible parts of the tuber. The \% DPPH scavenging activity was determined as 19.41 in sample $2 \mathrm{M}, 19.02$ in sample $1 \mathrm{M}$, 18.23 in sample $2 \mathrm{~S}, 14.78$ in sample $1 \mathrm{~S}$, respectively (Figure 4). 


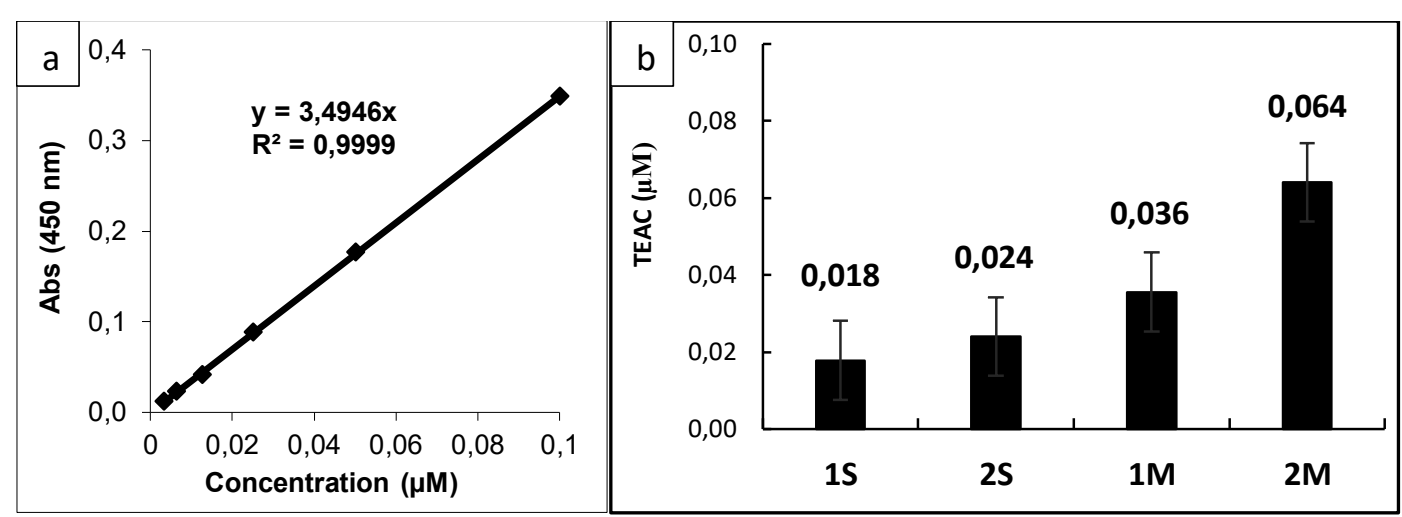

Figure 3. Calibration graphic of the Trolox standard studied at different concentrations (a) and CUPRAC values ( $\mu$ M TEAC) of water and methanolic extracts of the two parts of the tuber (b).

\section{Antioxidant Activity Analysis with \% DPPH}

Method: To determine the antioxidant activities, DPPH free radical scavenging test was applied to water and methanol extracts of both parts of the plant tuber. The DPPH radical scavenging method is commonly used in measuring the antioxidant activity of the phenolic compounds or plant extracts due to its easy to operate, rapid and sensitive nature (Uguzlar et al., 2012). Many plant extracts have antioxidant properties because they contain phytocomponents such as phenolic acids and flavonoids (Chu et al., 2000). When DPPH activity results were examined for the all the parts of the plant tuber, \% DPPH scavenging activity the methanol extracts was higher than that of the water extracts. In addition, as in all the tests, the highest activity values of \% DPPH in both methanolic and water extracts were found in the nonedible parts of the tuber. The \% DPPH scavenging activity was determined as 19.41 in sample $2 \mathrm{M}, 19.02$ in sample $1 \mathrm{M}$, 18.23 in sample $2 \mathrm{~S}, 14.78$ in sample $1 \mathrm{~S}$, respectively (Figure 4).

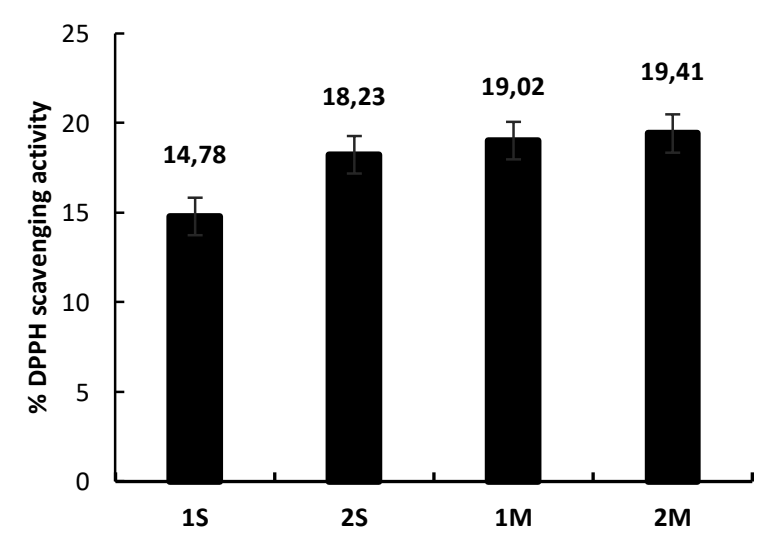

Figure 4. \% DPPH radical scavenging activity of water and methanolic extracts of the two parts of the tuber.

Phenolic Component Analysis by HPLC-UV and $\boldsymbol{L C}-\boldsymbol{M S} / \boldsymbol{M S}$ : The plants are rich source of secondary metabolite diversity. One of the most important groups of this metabolite diversity is phenolic compounds (Michalak,
2006). Phenolic compounds are present in plant parts such as fruit, leaves and stems and available in almost all plant parts. As their potential antioxidant properties and their possible role in preventing oxidative stress related diseases such as cancer, they have been attracted much attention (Odbayar et al., 2006).

Phenolic acids consist of two subgroups which are hydroxybenzoic acid and hydrocinnamic acid. In the study, the phenolic compositions of the methanolic extracts of the tuber were determined using both RP-HPLC-UV devices. In addition, methanol and dichloromethane extracts were prepared in LC-MS/MS devices.

The phenolic content in the samples was analyzed using 19 phenolic acid standards in RP-HPLC-UV device Table 2. More phenolic components were determined in the methanolic extracts of the nonedible parts than the edible part. In this case, the phenolic content is consistent with those of the antioxidant activity determination tests which are higher in nonedible part extract for all the tests.

Table 2. RP-HPLC-UV Phenolic Compounds.

\begin{tabular}{lcc}
\hline Standards & 1M( $\boldsymbol{\mu g}$ phenolic/g sample $)$ & 2M( $\boldsymbol{\mu g}$ phenolic/g sample) \\
\hline Gallic acid & - & - \\
Protocateuic acid & 6.02 & - \\
$p$-OH Benzoic acid & 4.539 & - \\
Catechin & - & - \\
Caffeic acid & - & 26.724 \\
Syringic acid & - & 13.179 \\
Epicatechin & - & 31.284 \\
$p$-Coumaric acid & - & 13.264 \\
Ferulic acid & - & 14.376 \\
Rutin & - & 247.754 \\
Myricetin & - & - \\
Resveratrol & - & - \\
Daidzein & - & - \\
Luteolin & 8.092 & - \\
$t$-Cinnamic acid & 4.970 & 2.696 \\
Hesperidin & - & - \\
Chrysin & - & - \\
Pinocembrin & - & - \\
CAPE & - & - \\
*-: Not Detected & &
\end{tabular}

Rutin and epicatechin were major flavonoid components and caffeic acid was determined as hydroxycinnamic acid derivatives in the nonedible part. At the same time, the phenolic components of the two parts of the tuber of the plant were performed using LC-MS/MS device with 20 phenolic standards (Table 3 ). While ferulic acid, p-coumaric acid, epicatechin, vanillin, caffeic acid, phydroxy benzoic acid and salicylic acid are identified as 
major components, rutin, catechin and taxipholine were measured at low levels at both parts of the tuber.

Table 3. LC/MS-MS Phenolic Compounds.

\begin{tabular}{|c|c|c|}
\hline Standards & $\begin{array}{c}\text { 1M( } \mu g \text { phenolic/g } \\
\text { sample })\end{array}$ & $\begin{array}{c}\mathrm{2M}(\mu \mathrm{g} \text { phenolic/g } \\
\text { sample })\end{array}$ \\
\hline Gallic acid & - & - \\
\hline Protocateuic acid & . & 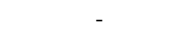 \\
\hline$p$-OH Benzoic acid & 0.179 & 0.189 \\
\hline Benzoic acid & & \\
\hline Catechin & 0.014 & 0.090 \\
\hline Caffeic acid & 0.579 & 0.716 \\
\hline Syringic acid & 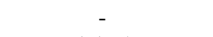 & - \\
\hline Epicatechin & 1.165 & 0.711 \\
\hline Salicylic acid & 0.159 & 0.108 \\
\hline Vanillic acid & - & \\
\hline$p$-Coumaric acid & 4.391 & 4.629 \\
\hline Ferulic acid & 11.131 & 10.800 \\
\hline Rutin & 0.014 & 0.021 \\
\hline Taxifolin & 0.003 & 0.007 \\
\hline Protocatechuic aldehyde & - & - \\
\hline Vanillin & 1.111 & 1.263 \\
\hline Rosmarinic acid & - & - \\
\hline Ellagic acid & - & - \\
\hline Oleuropein & - & - \\
\hline Resveratrol & - & - \\
\hline
\end{tabular}

Phenolic components defined and measured in both RP-HPLC-UV and LC-MS/MS are compatible with each other except for minor differences. Ağalar et al (2017) reported that the whole tuber part of Arum italicum has hydroxycinnamic acid derivatives such as ferulic, caffeic and $p$-coumaric acid in analysis with LC-MS/MS. The results obtained in both RP-HPLC-UV and LC-MS /MS are similar to the results of study by Ağalar et al (2017). Ağalar et al (2017) stated that ferulic acid and caffeic acid were present in the leaves of plants belonging to the Araceae family, also p-coumaric acid in the seeds of some species of the same family. Hydroxycinnamic acids containing ferulic acid, caffeic acid, and p-coumaric acid prevent metastasis or invasion of cancer cells (Ağalar et al., 2017). It has been pointed out that rutin exhibits many pharmacological activities such as antitumor, antimutagenic, antibacterial, anti-inflammatory, antiulcer, antidiarrheal, vasodilator, hepatoprotective activities and immunomodulator (Janbaz et al., 2002; Kamalakkannan \& Prince, 2006). In our study, rutin was detected in the nonedible part of the tuber with both RP-HPLC-UV and LC-MS/MS devices. It is known that this phenolic prevent ulcer in stomach where widespread in recent years. Ferulic acid was determined as $14.376 \mu \mathrm{g}$ phenolic/g sample in $2 \mathrm{M}$ part with RP-HPLC-UV, 10.800 in 2M sample and 11.131 $\mu \mathrm{g}$ phenolic/g sample in $1 \mathrm{M}$ sample by LC-MS/MS. It has been reported that ferulic acid can be useful in the treatment of chronic diseases with its biological activity (de Oliveira Silva \& Batista, 2017). In China, herbs rich in ferulic acid have been used in the repair of blood vessel damage and in the treatment of thrombosis diseases for many years (Ou \& Kwok, 2004). In addition, it has been reported that ferulic acid has very high antimicrobial activity, showed particularly strong inhibitory effects on the growth of some human gastrointestinal pathogenic microbiota including Helicobacteria pylori and Shigella sonnei (Lo \& Chung, 1999; Nilsson, 1999; Tsou et al., 2000).

\section{CONCLUSION}

It has been determined that the nonedible part of the tuber showed higher antioxidant activity than the edible part consumed as food in Arum italicum plant. Also, the phenolic profile determined by HPLC-UV and LCMS/MS devices is richer in the nonedible part. According to these results, although nonedible tuber part has a bad taste it can be concluded that the part can be consumed as food and used for treatment in alternative medicine.

\section{REFERENCES}

Ağalar, H.G., Çiftçi, G. A., Göger, F. \& Kırımer, N. (2017). Activity Guided Fractionation of Arum italicum Miller Tubers and the LC/MS-MS Profiles. Records of Natural Products, 12(1), 6475. DOI: 10.25135/RNP.06.17.05.089

Ahmed, H.A.A., Uranbey, S. \& Yaman, C. (2018). Efficient in vitro shoot induction of (Arum italicum MILLER) using shoot tips as medicinal and ornamental plant. Mediterranean Agricultural Sciences, 31(3), 295-300. DOI: 10.29136/mediterranean.451778

Akbulut, S. \& Özkan, Z.C. (2014). Traditional usage of some wild plants in Trabzon Region (Turkey). Kastamonu University Journal of Forestry Faculty, 14(1), 135-145.

Apak, R., Güçlü, K., Özyürek, M. \& Karademir, S.E. (2004). Novel total antioxidant capacity index for dietary polyphenols and vitamins $\mathrm{C}$ and $\mathrm{E}$, using their cupric ion reducing capability in the presence of neocuproine: CUPRAC method. Journal of Agricultural \& Food Chemistry, 52(26), 7970-7981. DOI: 10.1021/jf048741x

Arabshahi-Delouee, S. \& Urooj, A. (2007). Antioxidant properties of various solvent extracts of mulberry (Morus indica L.) leaves. Food Chemistry, 102(4), 1233-1240.

Benzie, I.F. \& Strain, J.J. (1996). The ferric reducing ability of plasma (FRAP) as a measure of "antioxidant power": the FRAP assay. Analytical Biochemistry, 239(1), 70-76. DOI: 10.1006/abio.1996.0292

Bozyel, M.E., Merdamert-Bozyel, E., Benek, A., Turu, D., Yakan, M.A. \& Canl, K. (2020). Ethnomedicinal Uses of Araceae Taxa in Turkish Traditional Medicine. International Journal of Academic \& Applied Research, 4(5), 78-87.

Brand-Williams, W., Cuvelier, M.E. \& Berset, C. (1995). Use of a free radical method to evaluate antioxidant activity. LWT-Food Science \& Technology, 28(1), 25-30. https://doi.org/10.1016/S0023-6438(95)80008-5 
Cai, Y., Luo, Q., Sun, M. \& Corke, H. (2004). Antioxidant activity and phenolic compounds of 112 traditional Chinese medicinal plants associated with anticancer. Life Sciences, 74(17), 2157-2184. DOI: 10.1016/j.lfs.2003.09.047

Can, Z., Yildiz, O., Sahin, H., Turumtay, E.A., Silici, S. \& Kolayli, S. (2015). An investigation of Turkish honeys: their physico-chemical properties, antioxidant capacities and phenolic profiles. Food Chemistry, 180, 133-141. DOI: 10.1016/j.foodchem.2015.02.024

Chu, Y.H., Chang, C.L. \& Hsu, H.F. (2000). Flavonoid content of several vegetables and their antioxidant activity. Journal of the Science of Food \& Agriculture, 80(5), 561-566.

de Oliveira Silva, E. \& Batista, R. (2017). Ferulic acid and naturally occurring compounds bearing a feruloyl moiety: a review on their structures, occurrence, and potential health benefits. Comprehensive Reviews in Food Science \& Food Safety, 16(4), 580-616. DOI: 10.1111/15414337.12266

Djeridane, A., Yousfi, M., Nadjemi, B., Boutassouna, D., Stocker, P. \& Vidal, N. (2006). Antioxidant activity of some Algerian medicinal plants extracts containing phenolic compounds. Food Chemistry, 97(4), 654-660. DOI: 10.1016/j.foodchem.2005.04.028

Erez, M.E., Dalar, A., Fidan, M. \& Pınar, S.M. (2019). Comprehensive appraisement of antioxidant potential and phytochemical profile of native botanicals from Turkey. Journal of Food Measurement \& Characterization, 13(4), 32303241. DOI: 10.1007/s11694-019-00245-X

Gidik, B., Akar, Z., Can, Z., Sefali, A. \& Erturk, O. (2019). Determination of antioxidant, antimicrobial activities, phenolic compounds of wild Rosa L. species Bayburt, Turkey. Fresenius Environmental Bulletin, 28(12), 9973-9982.

Gülcin, I. (2012). Antioxidant activity of food constituents: an overview. Archives of Toxicology, 86(3), 345-391. DOI: 10.1007/s00204-011-0774-2

Hirasa, K. \& Takemasa, M. (1998). Spice Science and Technology, CRC Press, New York, 232p.

Huang, D., Ou, B. \& Prior, R. L. (2005). The chemistry behind antioxidant capacity assays. Journal of Agricultural \& Food Chemistry, 53(6), 18411856. DOI: $10.1021 / \mathrm{jf030723 \textrm {c }}$

Janbaz, K.H., Saeed, S.A. \& Gilani, A.H. (2002). Protective effect of rutin on paracetamol-and $\mathrm{CCl}_{4}$-induced hepatotoxicity in rodents. Fitoterapia, 73(7-8), 557-563. DOI: 10.1016/S0367-326X(02)00217-4

Kamalakkannan, N. \& Prince, P.S.M. (2006). Antihyperglycaemic and antioxidant effect of rutin, a polyphenolic flavonoid, in streptozotocininduced diabetic wistar rats. Basic and Clinical Pharmacology \& Toxicology, 98(1), 97-103. DOI: 10.1111/j.1742-7843.2006.pto_241.x
Karahan, F., Kulak, M., Urlu, E., Gözüacik, H. G., Böyümez, T., Şekeroğlu, N. \& Doganturk, I.H. (2015). Total phenolic content, ferric reducing and DPPH scavenging activity of Arum dioscoridis. Natural Product Research, 29(17), 1678-1683. DOI: 10.1080/14786419.2014.991320

Lo, H.H. \& Chung, J.G. (1999). The effects of plant phenolics, caffeic acid, chlorogenic acid and ferulic acid on arylamine $\mathrm{N}$-acetyltransferase activities in human gastrointestinal microflora. Anticancer Research, 19(1A), 133-139.

Mau, J.L., Lin, H.C. \& Chen, C.C. (2002). Antioxidant properties of several medicinal mushrooms. Journal of Agricultural \& Food Chemistry, 50(21), 6072-6077. DOI: 10.1021/jf0201273

Michalak, A. (2006). Phenolic compounds and their antioxidant activity in plants growing under heavy metal stress. Polish Journal of Environmental Studies, 15(4), 523-530.

Ng, T.B., Liu, F. \& Wang, Z.T. (2000). Antioxidative activity of natural products from plants. Life Sciences, 66(8), 709-723. DOI: 10.1016/S00243205(99)00642-6

Nilsson, C.L. (1999). Fingerprinting of Helicobacter pylori strains by matrix-assisted laser desorption/ionization mass spectrometric analysis. Rapid Communications in Mass Spectrometry, 13(11), 1067-1071.

Odbayar, T.O., Badamhand, D., Kimura, T., Takahashi, Y., Tsushida, T. \& Ide, T. (2006). Comparative studies of some phenolic compounds (quercetin, rutin, and ferulic acid) affecting hepatic fatty acid synthesis in mice. Journal of Agricultural \& Food Chemistry, 54(21), 8261-8265. DOI: 10.1021/jf061135c

Ou, S. \& Kwok, K.C. (2004). Ferulic acid: pharmaceutical functions, preparation and applications in foods. Journal of the Science of Food \& Agriculture, 84(11), 1261-1269. DOI: 10.1002/jsfa.1873

Slinkard, K. \& Singleton, V. L. (1977). Total phenol analysis: automation and comparison with manual methods. American Journal of Enology and Viticulture, 28(1), 49-55.

Tosun, G., Arslan, T., Iskefiyeli, Z., Küçük, M., Karaoğlu, Ş.A. \& Yayli, N. (2015). Synthesis and biological evaluation of a new series of 4alkoxy-2-arylquinoline derivatives as potential antituberculosis agents. Turkish Journal of Chemistry, 39(4), 850-866. DOI: 10.3906/kim1501-112

Tsou, M.F., Hung, C.F., Lu, H.F., Wu, L.T., Chang, S.H., Chang, H.L., Chen, G.W. \& Chung, J.G. (2000). Effects of caffeic acid, chlorogenic acid and ferulic acid on growth and arylamine $\mathrm{N}$ acetyltransferase activity in Shigella sonnei (group D). Microbios, 101(398), 37-46.

Uguzlar, H., Maltas, E. \& Yildiz, S. (2012). Screening of phytochemicals and antioxidant activity of Arum dioscoridis seeds. Journal of Food Biochemistry, 36(3), 285-291. DOI: 10.1111/j.17454514.2010.00537.x 
Uttara, B., Singh, A.V., Zamboni, P. \& Mahajan, R.T. (2009). Oxidative stress and neurodegenerative diseases: a review of upstream and downstream antioxidant therapeutic options. Current Neuropharmacology, 7(1), 65-74. DOI: 10.2174/157015909787602823

Valko, M., Leibfritz, D., Moncol, J., Cronin, M. T., Mazur, M., \& Telser, J. (2007). Free radicals and antioxidants in normal physiological functions and human disease. The international Journal of Biochemistry \& Cell Biology, 39(1), 44-84. DOI: 10.1016/j.biocel.2006.07.001

Xiao, C.H., Yang, S.S. \& Hong, X.K. (2000). The chemistry of traditional Chinese medicines. Shanghai Science \&Technology Publishing House, Shanghai, 36, 505-507. 